will certainly be interesting to see what happens in 1961. If you see a Cardinal make careful notes of your observations and send them to the Editor of the Blue Jay. As chairman of the Prairie Nest Records Scheme, I should appreciate having anyone fortunate enough to locate a nest in Saskatchewan writing or phoning me at 3455 Rae Street, Regina.

\title{
Clark's Nutcracker, Unusual Visitor to Saskatchewan
}

\section{by Robert V. Folker, Saskatoon}

On August 18, 1960, when I was hiking in the "hills" northwiest of Ravenscrag, on the ranch of Billy Topham, I made what I considered a rather unusual bird observation. The bird was a Clark's Nutcracker ( Nucifraga columbiana). This species of the crow family is common in the Rocky Mountains, and I first became acquainted with it while skiing in the mountains north of Boise, Idaho. While I saw it only briefly, the striking pattern of its black and white wings and tail againsit the uniform gray body colour made it immediately recognizable. To my knowledge, there are only two other records for Saskatchewan, and both are from this immediate vicinity. In 1919 Spencer Pearse observed several on his ranch and collected a specimen on September 19. Six years later Pearse sa:w another, again in September (Godfrey, W. E. 1950. Birds of the Cypress Hills and Flotten Lake Regions, Sask. Nat'l Mus. Canada, Bull. No. 120).

This bird was seen in a unique bit of eroded benchland, located at the right elevation and with the necessary moisture to grow fair stands of spruce. The main valley is drained by Conglomerate Creek, otherwise known as the Little Frenchman River; this stream joins the Frenchman River at Ravenscrag. Numerous sidedrainages exist, most of them well woodied and with small, spring-fed streams flowing through them. The country offers impressive contrasts with semi-arid, sparsely-covered siopes merging with those that are overgrown with trees and shrubs.

Bird-life in this area appears to be as varied and interesting as the topography and the flora. On this particular trip I also noted a family of Rock Wrens flitting about over a pile of windcarved sandstone, daring to approach within thirty feet of me. A Turkey Vulture, catching the updrafts from bare, white hillsides, soared overhead. Mr. Topham reported he had oibserved four of these sciavengers through the summer, and believed they were -nesting somewhere in the area. At the mouth of one large draw, a group of Red-breasted Nuthatches were feeding among the spruce, joined at intervals by a flock of wheeling Pine Siskins. Further up this same draw, I came across a family of curious but shy Ovenbirds. It is quite probable that this is a valid nesting record for this species. Chickadees were observed several times as were White-crowned' Sparrows. A solitary Oregon Junco looked me over as I sat watching the Ovenbirds.

One can always look forward to seeing the unexpected in this intriguing valley and certainly this trip was no exception.

\section{ATTENTION! NEW PETERSON BIRD FIELD GUIDE}

Roger Tory Peterson's new revised Field Guide to the Western Birds (1961) is now available. The new guide really answers the need of Saskatchewan birders because it extends the range to cover the whole of the province (in fact, as far east as the 100th meridian). Formerly we had to use the western guide to supplement the eastern guide; in the revised western guide, all our species are listed in the one book.

In addition, all illustrations are new, and almost all are in colour.

Support the S.N.H.S. by buying your copy of the revised Field Guide to the Western Birds from the Blue Jay Bookshop, Saskaitchewan Natural Hisitory Society, Sask. Museum of Natural History, Regina. 